\title{
Additional Material Culture Remains from the Bowles Creek Site (41CE475) in Cherokee County, Texas
}

Timothy K. Perttula

Heritage Research Center, Stephen F. Austin State University

Kevin Stingley

Texas Archeological Stewardship Network, Texas Historical Commission

Follow this and additional works at: https://scholarworks.sfasu.edu/ita

Part of the American Material Culture Commons, Archaeological Anthropology Commons, Environmental Studies Commons, Other American Studies Commons, Other Arts and Humanities Commons, Other History of Art, Architecture, and Archaeology Commons, and the United States History Commons

Tell us how this article helped you.

This Article is brought to you for free and open access by the Center for Regional Heritage Research at SFA ScholarWorks. It has been accepted for inclusion in Index of Texas Archaeology: Open Access Gray Literature from the Lone Star State by an authorized editor of SFA ScholarWorks. For more information, please contact cdsscholarworks@sfasu.edu. 
Additional Material Culture Remains from the Bowles Creek Site (41CE475) in Cherokee County, Texas

\section{Creative Commons License}

\section{(c) (1) \&}

This work is licensed under a Creative Commons Attribution-NonCommercial 4.0 International License 


\title{
Additional Material Culture Remains from the Bowles Creek Site (41CE475) in Cherokee County, Texas
}

\author{
Timothy K. Perttula and Kevin Stingley
}

\section{Introduction and Context of Current Collection}

The Bowles Creek site is on a low alluvial rise in the Bowles Creek floodplain (Perttula et al. 2016); Bowles Creek is a southward-flowing tributary of the Neches River (Figure 1). Stingley found the site in early 2015 during a surface walk over, when Caddo ceramic sherds were noted in a number of gopher mounds. He excavated a number of shovel tests $(\mathrm{n}=13)$ and three units (generally 1 x $1 \mathrm{~m}$ in size)

(Figure 2); the units were excavated to between $50-80 \mathrm{~cm}$ bs. The site covers at least an estimated $55 \mathrm{~m}$ (east-west) x 20 m (north-south) area.

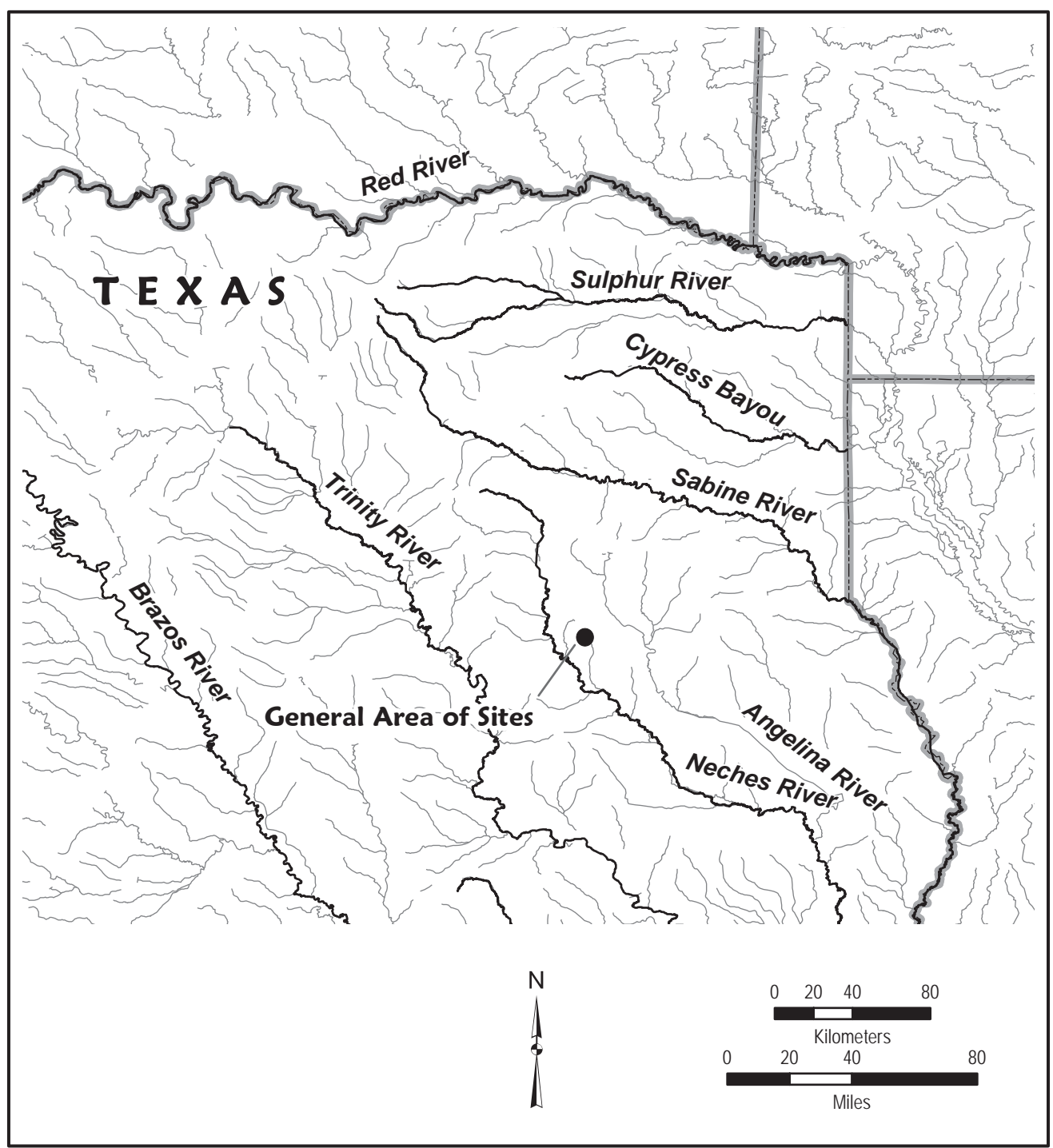

Figure 1. Location of the Bowles Creek site in East Texas. 


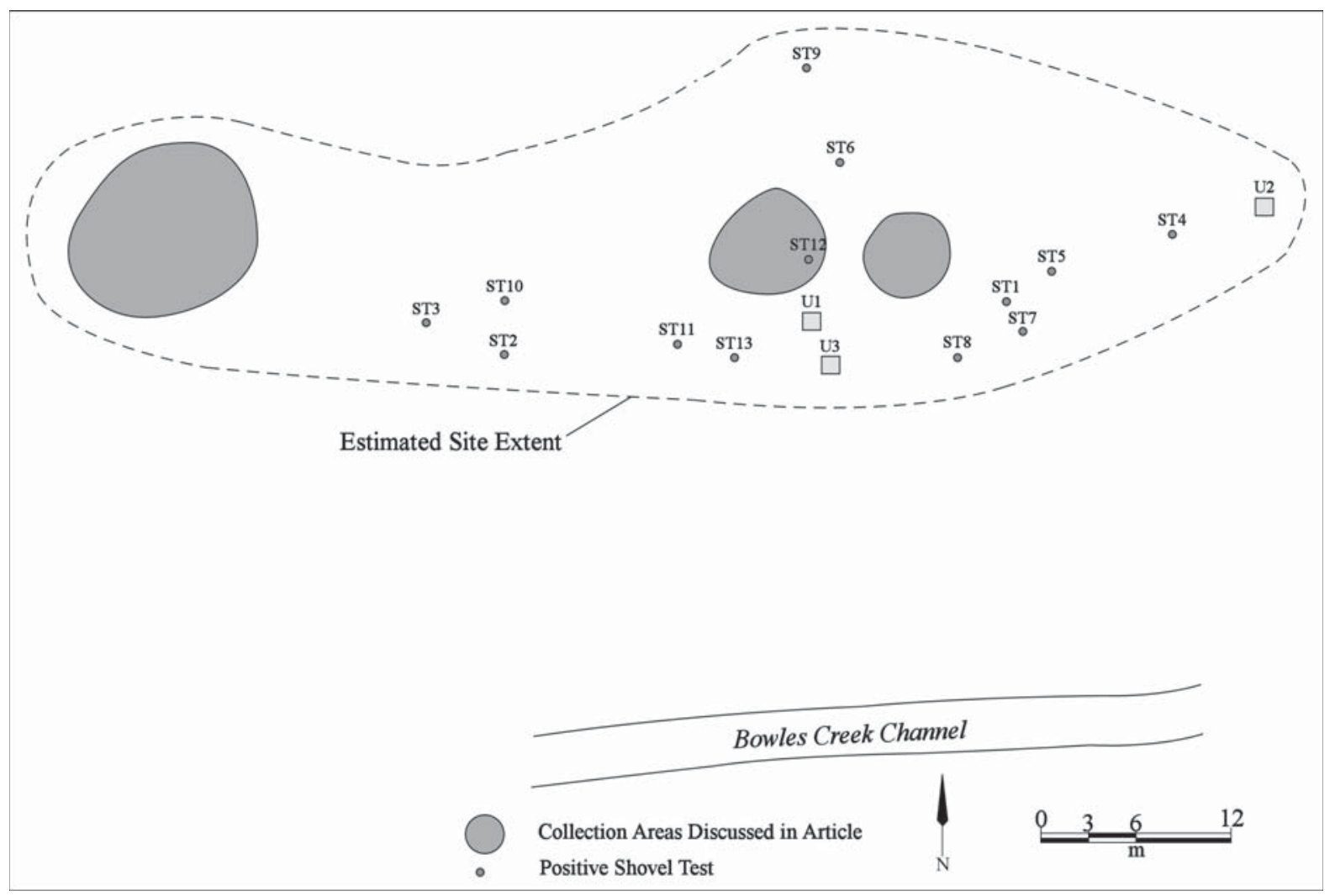

Figure 2. Map of the Bowles Creek site showing the location of shovel tests and hand-excavated units as well as collection areas of the material culture remains discussed in this article.

The initial archaeological investigations at the Bowles Creek site recovered 617 ceramic sherds (Perttula et al. 2016:Table 13), of which 461 were decorated. The plain to decorated sherd ratio in the assemblage was 0.34 . Almost 69 percent of the sherds were from utility ware jars, including sherds from Bullard Brushed, Spradley Brushed-Incised, Killough Pinched, and Lindsey Grooved vessels, and ca. 91 percent of the sherds from the site were from grog-tempered vessels, including sherds from vessels tempered with both grog and bone. Approximately 10 percent of the sherds were from bone-tempered vessels. Sherds from both Patton Engraved $(n=4)$ and Poynor Engraved $(n=6)$ vessels were present in the Bowles Creek site fine wares, along with one trailed sherd. The character of the recovered ceramics from the site suggest the ancestral Caddo occupation dated after ca. A.D. 1650, in the Allen phase, although the occurrence of both Poynor Engraved and Patton Engraved sherds in the assemblage (Perttula et al. 2016:Table 15) may indicate that the site was also used by Caddo peoples sometime before A.D. 1650, perhaps between ca. A.D. 1560-1650 in the latter part of the Frankston phase.

A single radiocarbon date has been obtained on a piece of animal bone from Unit 3, 40-50 cm bs, at the site (see Figure 2). The radiocarbon age of one AMS sample from the Bowles Creek site is $410 \pm 24$ years B.P. (D-AMS 11799), or A.D. $1540 \pm 24$. The 2 sigma calibration (95 percent probability) of this radiocarbon age, using IntCal13 (Reimer et al. 2013), is A.D. $1525 \pm 84$. This result further suggests that there are Frankston phase (ca. A.D. 1400-1650) archaeological deposits preserved at the site.

An additional sample of material culture remains from the Bowles Creek site was obtained by Stingley in July and August 2015, primarily from areas recently disturbed by wild hogs (see Figure 2). These remains are the subject of this article. 


\section{Material Culture Assemblage}

The collection of material culture remains from the Bowles Creek site includes ceramic vessel sherds, burned clay pieces $(n=2)$, a single arrow point, and a small number of unburned animal bones and teeth.

\section{Ceramic Sherds}

This collection has 337 ceramic sherds from plain ware, fine ware, and utility ware vessels (Table 1). Approximately 89.3 percent of the sherds - and 100.0 percent of the sherds from fine ware vessels - are from grog-tempered vessels, while 10.7 percent of the sherds are from bone-tempered vessels. The highest percentage of bone-tempered vessel sherds occur in the utility wares (11.3 percent).

Table 1. New ceramic sherd sample from the Bowles Creek site.

\begin{tabular}{llll}
\hline Ware & Grog temper & Bone temper & $\mathrm{N}$ \\
\hline Plain ware & 117 & 14 & 131 \\
Fine ware & 12 & - & 12 \\
Utility ware & 172 & 22 & 194 \\
\hline Totals & 301 & 36 & 337 \\
\hline
\end{tabular}

Of the 206 decorated sherds in this assemblage, only 5.8 percent are from fine ware vessels; these include both engraved and trailed sherds (Table 2). The one trailed sherd is from a bowl or carinated bowl and has several curvilinear trailed lines; this may be from a Keno Trailed vessel. One engraved body sherd is definitely from a Patton Engraved, var. unspecified vessel: it has a curvilinear engraved line with small excised tick marks.

Table 2. Decorative methods and elements in the new ceramic sherd sample from the Bowles Creek site.

\begin{tabular}{llll}
\hline Decorative Method and Element & Rim & Body & $\mathrm{N}$ \\
\hline
\end{tabular}

\section{Fine Ware}

\section{Engraved}

curvilinear engraved line with excised tick marks curvilinear hatched zone horizontal and diagonal engraved lines horizontal and vertical engraved lines with excised tick marks on horizontal engraved line parallel and curvilinear engraved lines and diagonal hatched zone parallel and diagonal engraved lines straight engraved line triangular excised zone

$\begin{array}{lll}- & 1 & 1 \\ - & 1 & 1 \\ 1 & - & 1 \\ 1 & - & 1 \\ - & & \\ - & 1 & 1 \\ - & & \\ - & 1 & 4 \\ - & 4 & 1\end{array}$

\section{Trailed}

curvilinear trailed line 
Table 2. Decorative methods and elements in the new ceramic sherd sample from the Bowles Creek site, cont.

\begin{tabular}{|c|c|c|c|}
\hline Decorative Method and Element & $\operatorname{Rim}$ & Body & $\mathrm{N}$ \\
\hline \multicolumn{4}{|l|}{ Utility Ware } \\
\hline \multicolumn{4}{|l|}{ Brushed } \\
\hline diagonal brushing marks & 1 & - & 1 \\
\hline opposed brushing marks & - & 1 & 1 \\
\hline overlapping brushing marks & - & 4 & 4 \\
\hline parallel brushing marks & - & 157 & 157 \\
\hline vertical brushing marks & 1 & - & 1 \\
\hline \multicolumn{4}{|l|}{ Brushed-Incised } \\
\hline $\begin{array}{l}\text { diagonal incised lines [lower rim] and horizontal } \\
\text { brushed on body }\end{array}$ & - & 1 & 1 \\
\hline \multicolumn{4}{|l|}{ Brushed-Punctated } \\
\hline $\begin{array}{l}\text { parallel brushing marks and tool punctated pushed } \\
\text { through the brushing }\end{array}$ & - & 2 & 2 \\
\hline $\begin{array}{l}\text { tool punctated row on folded lip and horizontal } \\
\text { brushing on the rim }\end{array}$ & 1 & - & 1 \\
\hline \multicolumn{4}{|l|}{ Incised } \\
\hline horizontal and cross-hatched incised lines & - & 1 & 1 \\
\hline parallel incised lines & - & 7 & 7 \\
\hline straight incised line & - & 8 & 8 \\
\hline \multicolumn{4}{|l|}{ Incised-Punctated } \\
\hline $\begin{array}{l}\text { tool punctated row on folded lip, and horizontal } \\
\text { incised line above tool punctated row on rim }\end{array}$ & 1 & - & 1 \\
\hline parallel incised lines and adjacent tool punctated row & - & 1 & 1 \\
\hline \multicolumn{4}{|l|}{ Pinched } \\
\hline parallel pinched ridges & - & 3 & 3 \\
\hline straight pinched ridge & - & 1 & 1 \\
\hline \multicolumn{4}{|l|}{ Punctated } \\
\hline fingernail punctated rows & - & 1 & 1 \\
\hline fingernail punctated row beneath the lip & 1 & - & 1 \\
\hline tool punctated row beneath the lip & 1 & - & 1 \\
\hline opposed tool punctated rows & - & 1 & 1 \\
\hline Totals & 8 & 198 & 206 \\
\hline
\end{tabular}

Several other engraved sherds are from Poynor Engraved vessels. One is a rim sherd from a Poynor Engraved, var. Freeman vessel (see Perttula 2011:Figure6-64h) that has a horizontal engraved line under the lip with excised tick marks along with a single vertical engraved line that serves as a panel divider 


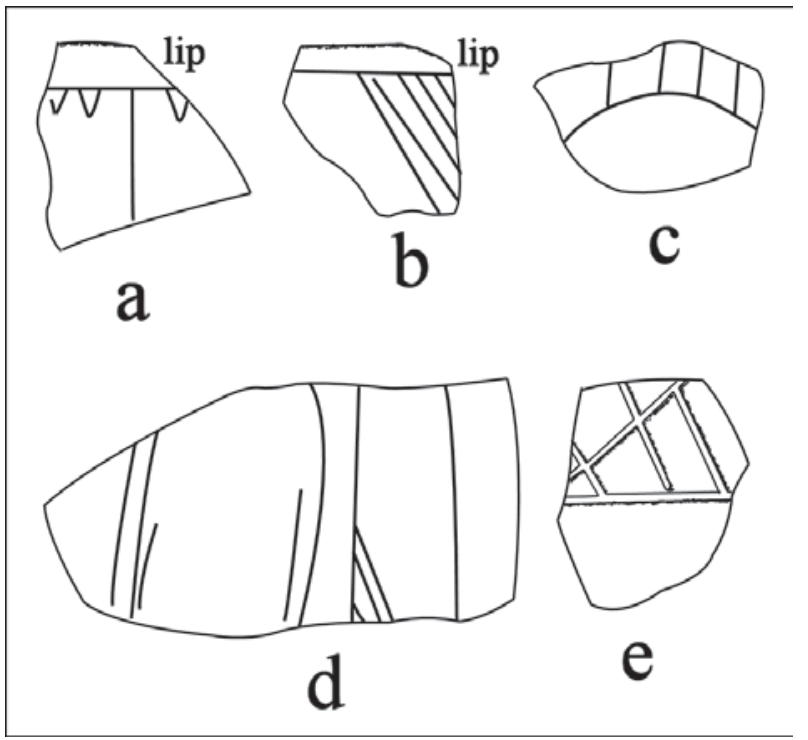

Figure 3. Selected decorative elements on sherds from the new collection from the Bowles Creek site.
(Figure 3a); a white clay pigment had been rubbed into the engraved lines and the excised tick marks. Another Poynor Engraved rim sherd has a horizontal engraved line beneath the lip and a hatched triangle element (Figure 3b), while a body sherd has a curvilinear hatched zone (Figure 3c). A second Poynor Engraved body sherd has parallel and curvilinear engraved lines and a small diagonal hatched element (Figure $3 d)$.

The utility ware sherds are dominated by rim and body sherds from Bullard Brushed jars (see Table 2); these sherds have brushed, brushedincised, and brushed-punctated decorative elements. Sherds with these decorative elements comprise 86.6 percentage of the utility wares, and 81.5 percent of all the decorated sherds in this new assemblage from the Bowles Creek site.

The incised sherds ( 8.3 percent of the utility wares in this assemblage) are likely all from Maydelle Incised vessels. One body sherd, from a carinated bowl, has both horizontal and cross-hatched incised lines (see Figure 3e). Two sherds have incised-punctated decorative elements (1 percent of the utility wares in this assemblage), one a rim with a distinctive tool punctated row on the folded lip, as well as a horizontal incised line above a horizontal tool punctated row on the rim itself, and the other a body sherd with parallel incised lines and an adjacent tool punctated row (see Table 2). Four body sherds with parallel or straight pinched ridges are from Killough Pinched jars (2.1 percent of the utility wares in this assemblage). Four other sherds, including rim and body sherds, are from vessels with rows of either tool or fingernail punctations (see Table 2;2.1 percent of the utility wares in this assemblage).

\section{Burned Clay}

The new collection from the Bowles Creek site has two small pieces of burned clay. These may be the remains of an earth oven or other sort of cooking feature that was in use at the site.

\section{Chipped Stone Tool}

A probable Cuney arrow point of gray novaculite is in the new collection from the Bowles Creek site. The arrow point is bifacially flaked, and has a long, narrow, and parallel stem with a slightly concave base and downward-pointing barbs. The point is $15.9 \mathrm{~mm}$ in length, $13.9 \mathrm{~mm}$ in width, $2.3 \mathrm{~mm}$ in thickness, and has a $3.5 \mathrm{~mm}$ stem width.

\section{Animal Bones}

There are 20 pieces of unburned animal bone and teeth (likely from a canid) in this collection. These were mainly collected a few meters north of Unit 1 (see Figure 2). 


\section{Summary of the Ceramic Assemblage from the Bowles Creek Site}

The combined ancestral Caddo ceramic assemblage from the Bowles Creek site has 667 decorated sherds (Table 3). Fine wares only account for 7.3 percent of the assemblage, and there are sherds from Patton Engraved, Poynor Engraved, and probable Keno Trailed vessels in the assemblage; Poynor Engraved is the most abundant fine ware, but Patton Engraved sherds are well represented (see Perttula et al. 2016).

Table 3. Decorated sherds in the combined Bowles Creek site ceramic assemblages.

\begin{tabular}{lll}
\hline Decorative method & $\mathrm{N}$ & Percentage \\
\hline Fine Ware & & \\
Engraved & 43 & 6.4 \\
Engraved-Brushed & 1 & 0.1 \\
Engraved-Punctated & 2 & 0.3 \\
Trailed $\quad 3$ & 0.5 \\
$\quad$ Subtotal, Fine Ware & 49 & 7.3 \\
$\quad$ Utility Ware & & \\
Brushed & & \\
Brushed-Incised & 555 & 83.2 \\
Brushed-Punctated & 5 & 0.7 \\
Grooved & 5 & 0.7 \\
Incised & 1 & 0.1 \\
Incised-Punctated & 29 & 4.3 \\
Pinched & 2 & 0.3 \\
Punctated $\quad$ Subtotal, Utility Ware & 7 & 1.0 \\
& 14 & 2.1 \\
Totals & 618 & 92.7 \\
\hline
\end{tabular}

Sherds from utility ware vessels dominate the ceramic assemblage, as 92.7 percent of the decorated sherds are from utility ware jars and bowls (see Table 3). Sherds from Bullard Brushed and Spradley Brushed-Incised vessels comprise more than 84.5 percent of all the decorated sherds in the assemblage, and more than 91 percent of all the utility ware sherds (see Table 3 ). The rest of the utility ware assemblage from the Bowles Creek site includes sherds from Maydelle Incised vessels and a few sherds from Killough Pinched and Lindsey Grooved jars. Untyped punctated sherds account for 2.1 percent of the decorated sherd assemblage from the site (see Table 3).

The Bowles Creek site is one of the few recognized sites in the Neche cluster. These are sites in the middle Neches River basin (and the Bowles Creek valley) that are likely affiliated with the Neche Caddo groups (see Marceaux 2011:499). Based on differences in certain ceramic attributes and sherd assemblage metrics. the Bowles Creek site is a Group II Neche cluster assemblage (Table 4). These differences in the Neche cluster sites likely have temporal differences, given the overall reduction in P/DR in ceramic sherd assemblages in Neches River basin Caddo sites, with the Group III site being the oldest, and probably dating from ca. A.D. 1560-1650, given the common occurrence of Poynor Engraved sherds in that assemblage, and the Group I and II sites likely dating after ca. A.D. 1650. The common occurrence of Poynor Engraved sherds in the Bowles Creek site assemblage also suggests that the Caddo occupation there likely began in the latter part of the Frankston phase, but the site was also occupied during Allen phase times. 
Table 4. Ceramic sherd assemblage comparisons of Neche cluster sites.

\begin{tabular}{llllll}
\hline Site & $\%$ Grog & \% Bone & P/DR & B/Pl & B/OWP** \\
\hline Group I & & & & & \\
41 CE293 & $98.1^{*}$ & $5.6^{*}$ & 0.12 & 7.50 & 5.70 \\
41 CE477 & 95.8 & 4.2 & 0.18 & 4.73 & 13.0 \\
41 CE474 & 97.1 & 2.9 & 0.30 & 3.08 & 9.25 \\
Group II & & & & & \\
41CE48 & 84.2 & 27.7 & 0.31 & 2.43 & 5.48 \\
41CE20 & 98.4 & 14.3 & 0.40 & 2.07 & 5.0 \\
Bowles & $\mathbf{9 0 . 2}$ & $\mathbf{9 . 8}$ & $\mathbf{0 . 4 3}$ & $\mathbf{1 . 9 7}$ & $\mathbf{9 . 0}$ \\
Creek & 91.2 & 9.2 & 0.45 & 1.77 & 7.0 \\
41CE476 & 97.4 & 2.6 & 0.30 & 1.94 & 1.84 \\
41CE291 & & & & & \\
Group III & N/A & N/A & 0.82 & 0.78 & 1.90 \\
\hline 41CE19, N & & & & & \\
\hline
\end{tabular}

$\mathrm{P} / \mathrm{DR}=$ plain to decorated sherd ratio; $\mathrm{B} / \mathrm{Pl}=$ brushed/plain sherd ratio; $\mathrm{B} / \mathrm{OWP}=$ brushed/other wet paste sherd ratio

*percentages will total to more than 100 percent because some sherds have more than one kind of temper **sherds with multiple decorative elements (i.e., brushed-incised or brushed-punctated, etc.) are counted as both brushed and as other wet paste sherds

The Group II sites all have Patton Engraved fine ware sherds, several-including the Bowles Creek site-have Poynor Engraved fine ware sherds. Bullard Brushed is the most common utility ware type in the Group II sites, as it is in the Group I and III sites, and there are also sherds of Maydelle Incised, La Rue Neck Banded, Lindsey Grooved, and Killough Pinched in several, but not all, of the Group II components.

\section{Conclusions}

The Bowles Creek site is an ancestral Caddo site on Bowles Creek in the Neches River basin in the East Texas Pineywoods. The site contains an abundance of ceramic vessel sherds from utility ware and fine ware vessels, primarily grog-tempered vessels, along with a Cuney arrow point, a few pieces of burned clay, and a small sample of unburned animal bone. Two collections of material culture remains have been obtained from the site in 2015 by the junior author, and they have been documented in this article as well as in Perttula et al. (2016).

The ceramic assemblage is indicative of a Group II site in the recently defined Neche cluster in the mid-Neches River basin. The Bowles Creek site assemblage has a low plain to decorated sherd ratio (0.43), a very high proportion of brushed utility ware sherds (ca. 85 percent of all the decorated sherds from the site), and a few sherds from Poynor Engraved and Patton Engraved fine ware vessels. Based on one calibrated radiocarbon date from an animal bone in Unit 3 at the Bowles Creek site, as well as the occurrence of both Poynor Engraved and Patton Engraved in the assemblage, it is likely that the site was first occupied during the latter part of the Frankston phase (ca. A.D. 1560-1650) by Neche Caddo peoples, and then occupied again sometime after ca. A.D. 1650. Hopefully, controlled excavations at the Bowles Creek site in the future can clarify the length and nature of the two different Caddo occupations, and the temporal interval of each occupation. 


\section{Acknowledgments}

Thanks to Lance Trask and Sandy Hannum for preparing the figures in this article.

\section{References Cited}

Marceaux, P. S.

2011 The Archaeology and Ethnohistory of the Hasinai Caddo: Material Culture and the Course of European Contact. Ph.D. dissertation, Department of Anthropology, The University of Texas at Austin.

Perttula, T. K.

2011 The Ceramic Artifacts from the Lang Pasture Site (41AN38) and the Place of the Site within an Upper Neches River Basin Caddo Ceramic Tradition. In Archeological Investigations at the Lang Pasture Site (41AN38) in the Upper Neches River Basin of East Texas, assembled and edited by T. K. Perttula, D. B. Kelley, and R. A. Ricklis, pp. 145-320. Archeological Studies Program Report No. 129, Texas Department of Transportation, Environmental Affairs Division, Austin.

Perttula, T. K., K. Stingley, and M. Walters

2016 Historic Caddo Archaeological Sites in Cherokee County, Texas. Journal of Northeast Texas Archaeology 65:1-24.

Reimer, P. J., E. Bard, A. Bayliss, J. W. Beck, P. G. Blackwell, C. Bronk Ramsey, C. E. Buck, H. Cheng, R. L. Edwards, M. Friedrich, P. M. Grootes, T. P. Guilderson, H. Haflidason, I. Hajdas, C. Hatte, T. J. Heaton, D. L. Hoffman, A. G. Hogg, K. A. Hughen, K. F. Kaiser, B. Kromer, S. W. Manning, M. Niu, R. W. Reimer, D. A. Richards, E. M. Scitt, J. R. Southon, R. A. Staff, C. S. M. Turney, and J. van der Plicht

2013 IntCal13 and Marine13 Radiocarbon Age Calibration Curves 0-50,000 Years Cal BP. Radiocarbon 55(4):1869-1887. 